Sains Malaysiana 50(4)(2021): 1143-1156

http://doi.org/10.17576/jsm-2021-5004-24

\title{
Oil Price Shocks and Energy Stock Returns of ASEAN-5 Countries: Evidence from Ready's (2018) Decomposition Technique in a Markov Regime Switching Framework
}

(Kejutan Harga Minyak dan Pulangan Stok Tenaga Negara-Negara ASEAN-5: Pembuktian daripada Teknik Penguraian Ready (2018) dalam Kerangka Peralihan Rejim Markov)

Adilah Azhari, Mukhriz Izraf AzMan AzIz, Yong Kang Cheah \& Hazrul Shahiri*

\section{ABSTRACT}

The present study applies a new decomposition technique by Ready (2018) to estimate the impact of oil price shocks on stock return in a Markov Regime Switching framework. The approach solves certain shortcomings of the novel procedure from Kilian by incorporating daily forward-looking prices of traded financial asset. The regime switching regression provides the evidence of strong nonlinear association of stock returns to risk shocks and demand shocks despite the absence of strong regime effects. We also demonstrate that positive demand shocks increase stock returns, whereas positive risk shocks negatively impact stock returns. For supply shocks, findings show that oil supply shocks do not significantly impact stock returns for Malaysia and Singapore. For Indonesia, supply shocks have a significant positive effect only in high volatility state. In the case of Thailand and the Philippines, the effects of supply shocks are negative and significant in high volatility state; but are not significant in low volatility state. Overall, our results suggest that demand shock has a greater economic impact than supply and risk shocks as demonstrated previously by Kilian and Park and Ready.

Keywords: Asymmetric; crude oil price; Markov switching; stock return

\section{ABSTRAK}

Kajian ini menggunakan teknik baru nyahkomposisi yang dibangunkan oleh Ready untuk menganggar kesan kejutan harga minyak kepada pulangan saham dalam Model Peralihan Rejim Markov. Pendekatan ini berupaya menyelesaikan beberapa kekurangan dalam prosedur terdahulu oleh Kilian dengan mengambil kira harga masa depan harian aset kewangan yang diniagakan. Regresi peralihan rejim menunjukkan bukti tentang kewujudan hubungan yang kuat antara pulangan saham dengan kejutan risiko dan permintaan walaupun tanpa penglibatan kesan rejim yang kuat. Kajian ini juga memaparkan kejutan permintaan yang positif memberi peningkatan pulangan saham manakala kejutan risiko yang positif memberi kesan buruk kepada pulangan saham. Bagi kejutan penawaran pula, keputusan menunjukkan kejutan penawaran minyak tidak mempunyai kesan yang signifikan kepada pulangan saham di Malaysia dan Singapura. Bagi Indonesia, kejutan penawaran mempunyai kesan positifyang signifikan hanya dalam keadaan apungan yang tinggi. Bagi Thailand dan Filipina, kesan kejutan penawaran adalah negatif dan signifikan dalam keadaan apungan yang tinggi tetapi tidak signifikan dalam keadaan apungan rendah. Secara keseluruhan, keputusan telah mencadangkan kejutan permintaan mempunyai impak ekonomi yang lebih besar daripada kejutan penawaran dan risiko seperti ditunjukkan oleh Kilian dan Park dan Ready.

Kata kunci: Harga minyak mentah; maklumat tak simetri; peralihan Markov; pulangan saham

\section{INTRODUCTION}

The present study employs Ready's (2018) technique to investigate the interaction of disentangled oil price shocks and energy stock returns using daily data from
January 1990 to January 2020 for five ASEAN countries. This study is similar to that by Zhu et al. (2017), which disaggregated oil shocks based on supply and demand shock for Markov-switching time regime (MRS) in high 
and low volatility states. To the best of our knowledge, no other research has examined the importance of oil price movements on energy stock returns for ASEAN-5 countries using Ready's (2018) approach in a MRS framework.

We conducted a two-stage approach in this study. First, we constructed the demand, supply and risk shocks in the crude oil market by utilising the identification technique developed by Ready (2018). Next, we analyzed the influence of decomposed oil price shocks on stock returns using Markov Regime Switching regression, which was originally developed by Hamilton (1989). We define demand shocks as portion of current returns from an index of oil producing firms that are independent from unanticipated variations in the VIX index. Next, supply shocks were derived from the residuals in the regression of oil price changes, demand shocks and unanticipated variations in the VIX index. Therefore, by definition, all the components of oil shocks (supply, demand and risk) represent all the variants in the changes of oil prices.

Next, the impact of decomposed oil shocks measures on stock returns was estimated using Markov Regime Switching regression. It is well known that modelling linear regression using macroeconomic time series variables may be subject to model misspecification error if structural changes are not incorporated (Granger 1996; Hansen 2001). Traditional linear regressions are incapable of capturing nonlinearity that exists between financial time series. MRS model overcomes this limitation by allowing regressors to switch between states or regimes. This allows the estimation of individual coefficients, which are regime dependent. This method is advantageous when nonlinearities are due to exogenous events (Hamidreza \& Maryam 2012; Hoque \& Shah Zaidi 2019; Ismail \& Isa 2006; Samsuddin \& Ismail 2019). This is essential to our study due to the nature of oil and stock markets where they are constantly subject to frequent economic and geopolitical events. Accordingly, we treat these events as exogenous in causing Markov's regime switch, irrespective of their impacts on stock prices and crude oil prices.

The majority of research on oil shocks impact on the stock markets focused on Western and industrialized countries (Arouri et al. 2011). However, there is a dearth of studies related to the interaction between oil price volatility and equities returns in developing countries, such as ASEAN countries. One of the most important characteristics for choosing the ASEAN-5 countries is because they are the key drivers behind strategic development in ASEAN. Moreover, they are the top five countries by economic size based on the World Economic Forum 2013 ranking in ASEAN (Sakane 2018). Emerging economies are growing at a faster rate than their developed peers. Total market capitalization of ASEAN-5 was only at USD1.8151 trillion in 2010. However, by 2018 the value jumped to USD2.331 trillion (Bakri \& Aisyah 2020). Emerging markets require higher energy consumption due to their accelerating economic growth and booming development, hence implying their reliance on energy supply and demand (Aloui et al. 2012). Due to the high instability in oil prices in recent years, Kisswani (2016) suggested that it is vital to analyze the influence of oil shocks in ASEAN countries.

This study attempts to contribute to the literature in two ways. First, we provide a comparative analysis of the impact of shocks on oil supply, and oil demand on energy-related stock returns in five ASEAN countries. Owing to the paucity of evidence on the oil-energy stock market nexus in the existing literature, the present study enriches the literature by examining a wide range of stock markets. Second, the present study is the first of its kind to analyse the differences between shocks of oil supply and oil demand using Ready's (2018) innovative classification technique. This method involves the forward-looking value of traded financial asset prices. Such approach solves certain shortcomings of the novel procedure by Kilian (2009) and permits us to make estimates using high frequency daily data.

We obtained several main results. First, linear baseline regressions indicate that demand shocks and risk shocks have notable positive and negative effects on equity returns, respectively. Nonetheless, low R squared model statistics (from $0.1 \%$ for Malaysia to $4.5 \%$ for Singapore) suggest a non-linear relationship among the variables. Second, we obtained a proof from MRS regression that the impacts of stock returns on risk and demand shocks are regime-independent. Nonetheless, there were some evidence of stronger demand-driven and risk-driven shocks in turmoil regime 1 relative to stable regime 2. Third, unlike risk and demand shocks, the impact of supply shocks on stock returns is regime dependent, as demonstrated by differing signs and size of coefficients for Indonesia, the Philippines and Singapore. Fourth, demand shocks usually have more effects on stock returns than supply and risk shocks, as evident by the magnitude and statistical significance of the coefficients. This result illustrates that there is a greater economic impact demand shock on the economy when compared to supply and risk shocks as previously shown by Kilian and Park (2009) and Ready (2018).

The remainder of this paper is organized as follows. The next section provides an overview of ASEAN economies and followed by a review of literature on the 
relationship between oil and stock market. The paper continues with description of data using Ready (2018) methodology and Markov Switching regression. This is then followed by the presentation of the empirical findings. Final section concludes the paper.

\section{OVERVIEW OF ASEAN ECONOMIES}

The Association of South East Asian (ASEAN) was founded on 8 August 1967 to promote regional peace, political stability and stimulate economic growth among its members of vast ethnic diversity. It started with only 5 member countries and has now grown to 10 member countries. In 2014, the combined population had reached 622 million (third populous in the world after China and India) with GDP of US\$2.5 trillion (Kobayashi et al. 2018). Nowadays, ASEAN has evolved from its main concern of regional security to boosting economic development via export and international trade (Pan \& Nguyen 2018). Furthermore, the ASEAN Economic Community (AEC) was formed on 31 December 2015 to strengthen the regional economic cooperation in 4 pillars; i.e. to provide single market and manufacturing base, dynamic economic zone, balanced economic growth and global economic integration (Kobayashi et al. 2018).

This initiative has placed ASEAN at the frontier of growing regions in the world due to its accelerated economic growth. ASEAN 5 countries reported more than $6 \%$ economic growth in 2010 , and this rapid development in infrastructure must be insured through undisturbed supply of energy (Basnet \& Upadhyaya 2015). In most ASEAN countries, the share of trade in oil is higher than many other countries in the world; whereby in 2015, the shares of total trade for Indonesia and Singapore were 15.7 and $16.3 \%$, respectively (Wu \& Nakata 2014). In the Asia Pacific Region, ASEAN owns nearly $40 \%$ of oil and gas reserve, but Singapore, Thailand and Philippines still rely heavily on foreign sources for oil (Basnet \& Upadhyaya 2015). Therefore, oil price volatility will have a major influence on these oil producing countries in ASEAN.

Among ASEAN-5, only Malaysia is the net oil supplier, whereas Indonesia and Thailand are the main energy consumers. Singapore has a thriving oil refining industry, albeit without any oil supplies, whereby this contributes significantly to the city-state economy. Given the role of ASEAN-5 economies in the world economy and their position in the oil and consumer commodity markets, it is important to understand the association between ASEAN-5 stock returns and oil prices. This is especially true for oil-producing countries such as Malaysia and Indonesia, which have become more dependent on oil imports due to declining local production. This situation is exposing them to adverse cyclical oil shock effects.

\section{LITERATURE REVIEW}

It is well-known that oil price shocks can impact the returns of the equity market across the globe. Policymakers and investors have been using the oil price volatility for their portfolio diversification and investment decision, energy policy and planning, as well as risk management (Awartani \& Maghyereh 2013). Previous findings were inconclusive on the association between oil shocks and returns of stock (Manal \& Tamat 2020). Sadorsky (1999), who utilised vector autoregression (VAR) approach found that individual shock to oil prices is negatively related to stock returns. However, shocks to the returns of stock market have a positive influence on the interest rate and production of various industries. In another study, Cunado and Gracia (2014) investigated the oil shock effects on stock returns in twelve European countries using vector error correction (VECM) and VAR models. The results showed a major negative influence of oil price shocks in several European countries. They constructed the demand and supply shocks by looking between changes in oil prices and changes in world oil output. Also, the study identified a greater sensitivity between equity returns and oil supply shocks than oil demand shocks because of a larger opposite effect.

The majority of research on oil shocks influence on the stock markets focused on Western and industrialized countries (Arouri et al. 2011). Other researchers investigated stock returns in China's energy market (Broadstock et al. 2012), energy index for Asia Pacific region (Broadstock et al. 2014), oil importing and oil exporting countries (Zhu et al. 2017), GCC countries (Arouri et al. 2011), individual countries e.g. Nigeria (Adaramola 2012), India (Ghosh \& Kanjilal 2016), Arab Spring (Bouri et al. 2016) and Islamic composite index (Badeeb \& Hooi 2018). Varying differences of impact are evident as stock returns may react differently based on supply and demand driven shocks (Zhu et al. 2017). Other studies noted that there are marked variations in the influence of oil price changes in high and low turmoil states (Basher et al. 2018; Bouri 2015; Kilian 2009). The majority of empirical works used Kilian's (2009) approach. For example, Basher et al. (2012) employed the Kilian's (2009) estimation for three variables, i.e. oil supply, real oil price, and global economic activity for emerging countries. They found that oil shocks will depress stock returns; but increases in emerging stock market prices will increase oil prices due to demand for energy in emerging markets.

Bouri et al. (2016) suggested that in the major oil producing countries like GCC, oil price volatility has a stronger and bi-directional impact on stock market. This is due to bigger share of energy and gas sectors compared to non-energy related stocks. By decoupling energy index 
from stock index, the real magnitude of oil price shocks effect can be further explained by oil exporting countries. Furthermore, Lee et al. (2012) contended that examining sectoral equity index is far more revealing compared to broad market index as oil prices' movement may affect different sectors in unequal ways. Moreover, using a sample of 70 countries of high and low oil producers, Gupta (2016) reported that companies in top oil-producing countries are more susceptible to oil price shocks and global uncertainties.

In China, global oil prices are correlated with energy-link stock especially after global financial crisis in 2008 due to sensitivity of these stocks to oil price shocks (Broadstock et al. 2012). Elyasiani et al. (2011) concurred that higher oil prices impact different industries in dissimilar patterns. They attributed this to the varying reliance on oil and energy. Certain industries are sensitive to the oil price movement whereby they will show statistically significant results compared to others. Focusing on oil and gas companies, recent study by Kang et al. (2017) found that oil-demand shock has a positive influence on the average stock returns. This is especially significant for upstream companies in the first ten months, which was attributed to $14.1 \%$ of the variation in the stock returns.

Broadstock et al. (2014) studied the direct and indirect impact of oil shocks on stock returns for energy related stock portfolio in Asia Pacific Region. They argued that certain industries will not experience an immediate impact by the changes in oil prices. Using the GARCH model to estimate the impact of oil shocks on stock yields, their results show that there is an unclear direct effect. However, there is an indirect effect on the daily stock returns. Reboredo (2008) reported that S\&P 500 and FTSE returns are negatively significant during turbulent state, but are insignificant in other state. Recently, Demirer et al. (2019) employed the Ready (2018) approach to determine the impact of oil price shocks on equity exchange and sovereign debt market. They found that oil demand shocks have adverse effects on the financial markets. Meanwhile, oil supply shocks weakly influence stock and sovereign bond returns in different country groups.

Notwithstanding, several studies have addressed the issue of oil price shocks and stock markets in ASEAN countries. For example, Hoque et al. (2019) explored the effect on stock prices in Malaysia in relation to geopolitical risk, economic policy uncertainty, and oil price shocks using an augmented SVAR approach. The findings from oil shocks suggest that oil-related shocks have asymmetric effects both on aggregate and sectoral stock prices. The implications of the oil demand shock on market prices are compounded by the global economic uncertainty factor, whereas the impact of the oil supply is intensified by the geopolitical risk factor. Meanwhile, Maneeju et al. (2018) examined this relationship using mixed copulas approach and found positive correlation between oil price increase and stock return for Malaysia, Thailand, and Indonesia. Meanwhile, there is a negative correlation for Singapore and the Philippines. Hersugondo et al. (2015) concluded that oil price changes only give positive significant effects on Malaysia and Thailand's stock market returns but insignificant effects on Indonesia, Singapore, and the Philippines. To a lesser extent, Hossenidoust (2013) found that volatility of the crude oil price can affect the stock markets in Malaysia and Singapore. In contrast, the stock markets of Indonesia, the Philippines and Thailand can provide a good hedging against the oil market's fluctuations. These results are corroborated by Darinda and Permana (2019) who confirmed that most of the ASEAN-5 stock markets benefit from the increasing level of oil prices during the 'High-Oil Price' era (between January $2^{\text {nd }}, 2012$, and December $5^{\text {th }}, 2014$ ).

\section{MATERIALS AND METHODS}

\section{DATA DESCRIPTION}

The analysis begins by deconstructing the oil price shocks into demand, supply and risk components based on the novel classification by Ready (2018). There are three prerequisite variables where they are necessary in decomposing the oil price shocks series: World Integrated Oil and Gas Producer Index (WIOGP), one-month crude oil future returns on the second nearest maturity for the New York Mercantile Exchange (NYMEX), and CBOE VIX index. The WIOGP index represents global oil producers' stock prices and includes major publicly traded oil companies. The New York Mercantile Exchange (NYMEX) oil future contract is used for oil price changes. The innovations in VIX are estimated as the residuals from an ARMA $(1,1)$ model are used to identify shocks associated with shifts in the risk premium that appear to be negatively correlated with equity returns (Bollerslev et al. 2009).

We used energy stock market index of Indonesia, Malaysia, Singapore, and Thailand. Meanwhile, for the Philippines, we used oil stock index. Data were supplied by Bloomberg and DataStream International. We used daily series that have different periods by country due to data constraints. For Malaysia, the Philippines and Thailand, the models were estimated over the period from January 2, 1990 to January 21, 2020. For Indonesia, the estimation period is from July 31, 1990 to January 21, 2020, and for Singapore it is from November 14, 1990 to January 21, 2020 . 


\section{DISENTANGLING OIL PRICE SHOCKS AND THE VAR} MODEL

Ready (2018) proposed a technique of identification that broke down changes in oil price into three components: Supply shocks, demand shocks and risk shocks. Following his approach, the decomposition model by Ready (2018) can be written as:

$$
X_{t}=A Z_{t}
$$

where $X_{t}=\left[\begin{array}{lll}\Delta p_{t} & R_{t}^{\text {Prod }} & \zeta_{V I X, t}\end{array}\right]$, is a $3 \times 1$ vector, $\Delta p_{t}$ is changes in oil prices, $R_{t}^{\text {Prod }}$ is return on WOIGP, and $\left.\zeta_{V I X, t}\right]$, represent innovations to VIX. $Z_{t}=\left[\begin{array}{ll}\Delta p_{t} & R_{t}^{\text {Prod }}\end{array}\right.$ $\left.\zeta_{V I X, t}\right]$, is a $3 \times 1$ is a vector of supply shocks $S_{t}$, demand shocks $D_{t}$, and risk shocks $\mathrm{V}_{t}$. Lastly, $A$ is a $3 \times 3$ matrix

$$
A \equiv\left[\begin{array}{ccc}
1 & 1 & 1 \\
0 & a_{22} & a_{23} \\
0 & 0 & a_{33}
\end{array}\right]
$$

To ensure orthogonality, the following criterion by Ready (2018) is fulfilled

$$
A^{-1} \sum_{X}\left(A^{-1}\right)^{T}=\left[\begin{array}{ccc}
\sigma_{S}^{2} & 0 & 0 \\
0 & \sigma_{d}^{2} & 0 \\
0 & 0 & \sigma_{v}^{2}
\end{array}\right]
$$

The covariance matrix of the discernible term $X_{t}$ is shown by $\sum_{X}$ in above equation, whereas $\sigma \mathrm{s}, \sigma \mathrm{d}$, and $\sigma \mathrm{v}$ are representing the volatilities of demand, supply and risk shocks, respectively. The typical orthogonalization process that is intuitively used to identify structural shocks is renormalized by identifications in the VAR context. In addition, we are aggregating the shocks to reflect total oil price changes instead of standardizing shock volatility to one.

\section{MARKOV REGIME SWITCHING MODEL}

Prior to MRS estimation, we started by estimating baseline linear regressions. This involves regressing the stock return for each ASEAN5 country on decomposed oil price shocks based on Ready (2018) classification. The model of estimation is given by:

$$
R_{i, t}=\beta_{0, i}+\beta_{1, i} S_{t}+\beta_{2, i} D_{t}+\beta_{3, i} \mathcal{V}_{t}+\mu_{i, t}
$$

where $R_{i, t}$ is the return on energy stock for country $i$ at time $t$ and and $S_{t}, D_{t}$ and $V_{t}$ are the supply shocks, demand shocks and risk shocks, respectively. $R_{i, t}$ is constructed using $R_{i, t}=100 \times \ln \left(s_{t} / s_{t-1}\right)$, where $s_{t}$ the is daily energyrelated index stock market at time $t$. Next, we proceed to estimating the following MRS regression:

$$
R_{i, t}=\beta_{0, i, m_{t}}+\beta_{1, i, m_{t}} S_{t}+\beta_{2, i, m_{t}} D_{t}+\beta_{3, i, m_{t}} \mathcal{V}_{t}+\mu_{i, t}
$$

where $\beta_{0, i, m_{t}}, \beta_{1, i m}, \beta_{2, i, m_{t}}$ and $\beta_{3, i, m_{t}}$ are slope coefficients that depend on regime $m$ at time $t$. When constructing the regime switching framework, we assume that the elasticity between oil price shocks and stock returns is regime $\left(m_{t}\right)$ dependent. The stochastic regime switching process is assumed to follow first order Markov process with finite number of regimes $(M)$ as follows:

$P_{l m}=\operatorname{Pr}\left(r_{t+1}=m \mid r_{t+1}=1\right), p l m \geq 0, \sum_{m=1}^{M} P l m=1$

Therefore, the transition probability for a two-regime Markov switching is as follows:

$$
P=\left(\begin{array}{ll}
p_{11} & p_{21} \\
p_{12} & p_{22}
\end{array}\right)
$$

where $p_{i j=} P\left(S_{t}=j \mid m_{t-1}=i\right)$ with $\sum_{j=1}^{2} p_{i j}=1$ for regime $\mathrm{i}(\mathrm{i}=1,2)$.

\section{RESULTS AND DISCUSSION}

Figure 1 illustrates the VIX index, oil output index, and oil prices. From 1990 to 2004, oil production remains almost constant after which a steady rise is observed following the global financial crisis. A rapid decrease in oil production occurs during GFC. However, in the post-GFC era, output level has increased and remained persistent to date. Oil prices show an almost identical pattern. Since 2003, real oil prices displayed a steady increase, despite a sharp decline in 2008. While the world economy improves, oil price has been fluctuating and rising. World oil price plummeted in the second half of 2014. The VIX index is constant throughout the entire period of the study, with only a marginal increase in volatility during the GFC from 2008 to 2009. Figure 2 indicates that, over time, every energy stock market index encountered significant volatility. Moreover, energy stock market index plots provide no evidence of a linear relationship.

Figure 3 shows a 720-day rolling correlation (RC) between crude oil price and stock returns. One of the main benefits of rolling correlation is that we can visualize the correlation change over time. Figure 3 shows a general upward trend from 2002 to about 2012, and a general downward trend later. These findings are generally applicable to all ASEAN countries. RC findings indicate a weak negative correlation from early 2000 to 2003, but it is positive afterwards. Following a significant positive correlation until about 2014, the correlation diminishes 
and becomes negative between 2014 and 2016 before recovering from 2017 onwards. Ultimately, the shift in the association between disentangled oil price shocks and stock returns of around positive and negative values supports the application of MRS. This is because a standard linear regression model may be inadequate to address the non-linearities (Hansen 2001).

Table 1 summarizes the statistics for decomposed oil price shocks variables and stock returns. Supply shocks and demand shocks appear to have zero mean values. However, negative mean value is recorded for risk shocks. Supply and demand shocks show negative skewness against the positive skewness for risk shocks. Nevertheless, all shock variables show excess kurtosis, displaying elements of leptokurtosis and a fat-tail for monetary variables. The Anderson-Darling normality test shows that none of the series are normally distributed. Among the stock returns, Thailand has the highest daily mean, and the lowest is Indonesia. Thailand's higher energy stock returns reflect its higher standard deviation. Malaysia's energy stock return has the lowest standard deviation, rendering it as a potential diversifier. High amount of kurtosis implies the probability of high yields compared to those found in the normally distributed series. For all stock returns, the null hypothesis of normality is rejected at $1 \%$ level of significance.
We examined the time series properties of the data by employing the DF-GLS test (Elliot et al. 1996) and KPSS (Kwiatkowski et al. 1992) test. The DF-GLS tests the null hypothesis of a unit root, while the KPSS tests the null hypothesis of stationarity. In summary, evidence from Table 2 shows that all variables are stationary, whether or not an intercept and linear trend are involved. Specifically, DF-GLS and KPSS test findings describe the three oil shocks as stationary at level except for supply shock where only the trend specification supports it. Further, the DFGLS test shows stock returns are I(0) at 5\% significance level for both constant and trend specifications. The KPSS test supports the stationarity properties for all cases. These results are compatible with those of Uddin et al. (2018).

The next step is to examine spatial reliance of the stock returns. We choose the BDS test (Broock et al. 1996) to assess the dispersion pattern of shock returns, and to determine if these series exhibit nonlinear structure. Results from Table 3 show that the null hypothesis of linearity is rejected at $1 \%$ significance level, suggesting that the stock returns series are nonlinearly dependent and exhibit chaotic behaviour for all dimensions $(\mathrm{m}=2$, $3, \ldots, 6)$. This nonlinearity structure in stock returns is also supported by the time series plots depicted in Figures 1-3 and Tables 1-3.
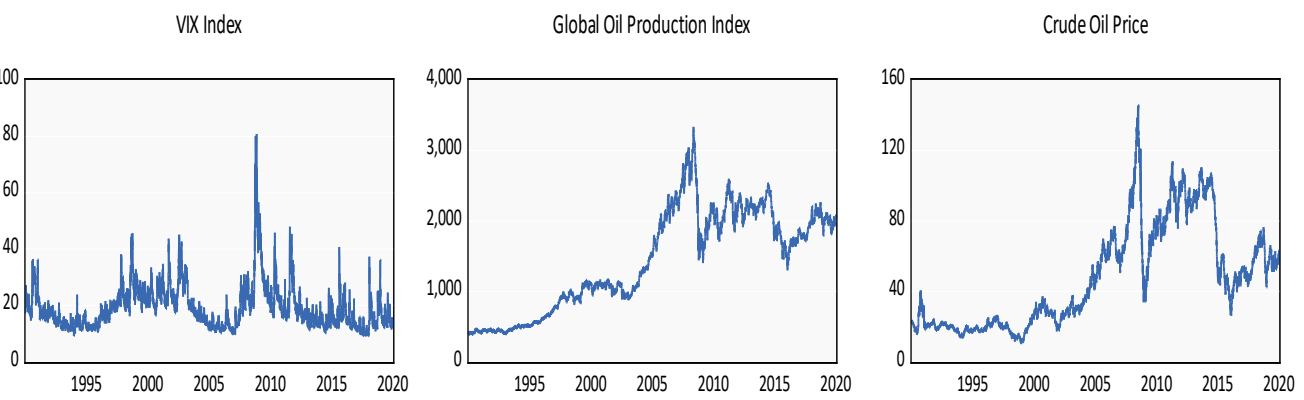

FIGURE 1. Time-trends of VIX index, global production index, crude oil price
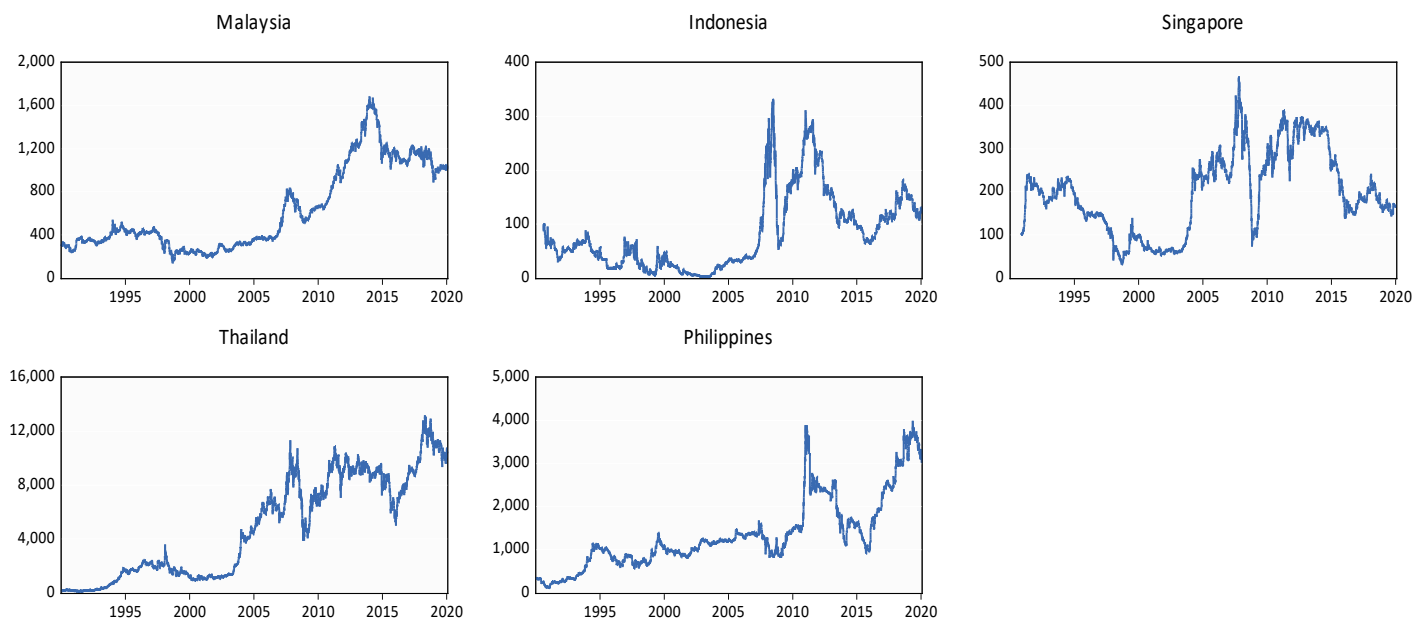

FIGURE 2. Time trend of stock indices

Notes: Malaysia: Energy Price Index, Indonesia: Energy Price Index, Singapore: Energy Price Index, Thailand: Energy Price Index, Philippines: Oil Price Index 

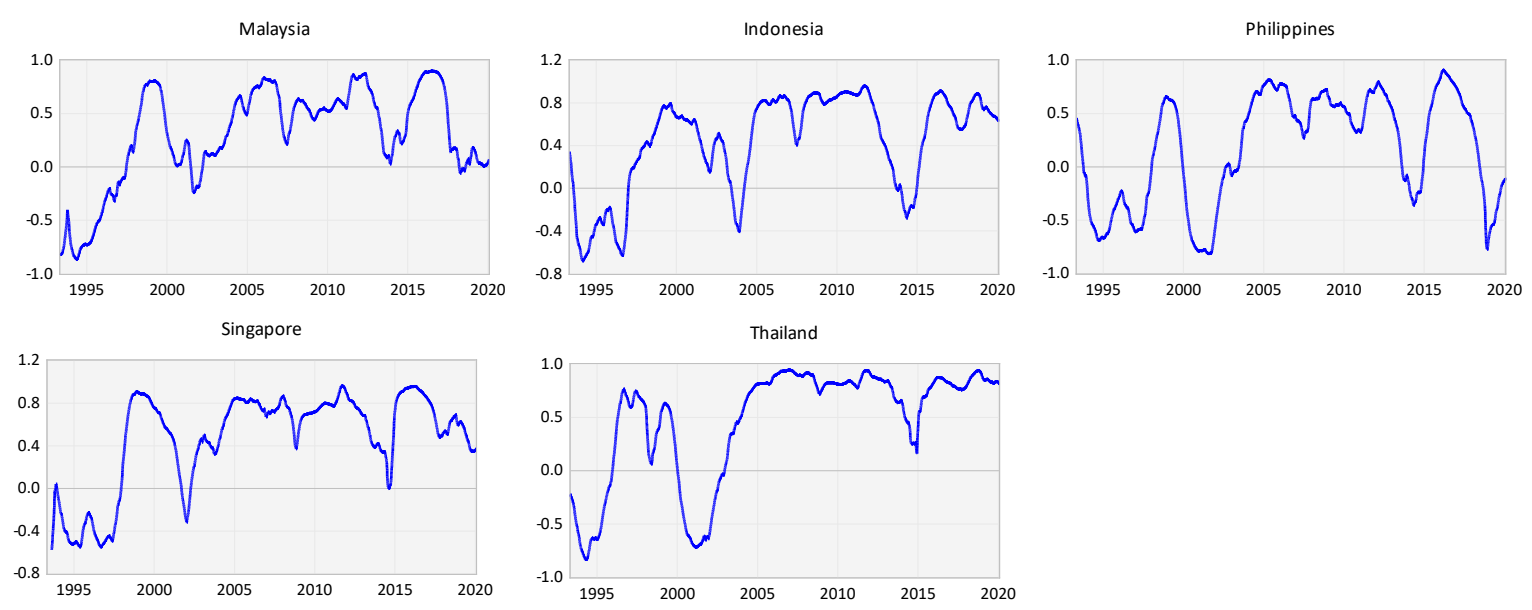

FIGURE 3. 720-days rolling correlation between crude oil price and stock market index

TABLE 1. Summary statistics of variables

\begin{tabular}{lcccccc}
\hline & Mean & Std. Dev. & Skewness & Kurtosis & A-D & \# of Obs. \\
\hline Demand shock & 0.000 & 1.041 & -0.03 & 10.433 & $73.765^{* * *}$ & 7840 \\
Risk shock & -0.005 & 6.395 & 1.035 & 10.129 & $80.003^{* * *}$ & 7840 \\
Supply shock & 0.000 & 2.159 & -0.898 & 23.967 & $87.44^{* * *}$ & 7840 \\
Indonesia & 0.003 & 5.549 & -0.53 & 50.06 & $939.22^{* * *}$ & 7690 \\
Malaysia & 0.016 & 1.51 & -0.677 & 64.44 & $263.09^{* * *}$ & 7840 \\
Singapore & 0.007 & 1.978 & 0.34 & 27.537 & $290.54^{* * *}$ & 7614 \\
Thailand & 0.055 & 2.232 & 0.125 & 9.494 & $155.8^{* * *}$ & 7840 \\
Philippines & 0.028 & 1.76 & -0.308 & 34.773 & $277.78^{* * *}$ & 7840 \\
\hline
\end{tabular}

Notes: A-D stands for Anderson-Darling normality test

TABLE 2. Unit root tests

\begin{tabular}{lcccc}
\hline & DF-GLS & \multicolumn{2}{c}{ KPSS } & Trend \\
\cline { 2 - 4 } & Constant & Trend & Constant & 0.0146 \\
\hline Supply Shocks & -1.573 & $-3.378^{* *}$ & 0.0270 & 0.1135 \\
Demand Shocks & $-30.022^{* * *}$ & $-62.851^{* * *}$ & 0.360 & 0.010 \\
Risk Shocks & $-2.968^{* * *}$ & $-6.566^{* * *}$ & 0.015 & 0.076 \\
Malaysia & $-7.392^{* * *}$ & $-22.130^{* * *}$ & 0.084 & 0.016 \\
Indonesia & $-51.494^{* * *}$ & $-51.496^{* * *}$ & 0.027 & 0.046 \\
Philippines & $-13.915^{* * *}$ & $-18.630^{* * *}$ & 0.052 & 0.107 \\
Singapore & $-3.575^{* * *}$ & $-6.563^{* * *}$ & 0.123 & 0.055 \\
Thailand & $-2.504^{* *}$ & $-5.736^{* * *}$ & 0.266 & \\
\hline
\end{tabular}

Notes: $* * *, * *$, and $*$ refer to significance at the $1 \%, 5 \%$, and $10 \%$ levels, respectively 
TABLE 3. BDS tests for stock market returns

\begin{tabular}{lccccc}
\hline Dimension & BDS Statistics & & & & \\
\hline$m$ & Malaysia & Indonesia & Philippines & Singapore & Thailand \\
2 & $0.0275^{* * *}$ & $0.0403^{* * *}$ & $0.0355^{* * * *}$ & $0.0308^{* * *}$ & $0.0244^{* * *}$ \\
& {$[0.000]$} & {$[0.000]$} & {$[0.000]$} & {$[0.000]$} & {$[0.000]$} \\
3 & $0.0525^{* * *}$ & $0.0758^{* * *}$ & $0.0678^{* * *}$ & $0.0583^{* * *}$ & $0.0484^{* * *}$ \\
& {$[0.000]$} & {$[0.000]$} & {$[0.000]$} & {$[0.000]$} & {$[0.000]$} \\
4 & $0.0685^{* * *}$ & $0.1005^{* * *}$ & $0.0924^{* * *}$ & $0.0795^{* * *}$ & $0.0656^{* * *}$ \\
& {$[0.000]$} & {$[0.000]$} & {$[0.000]$} & {$[0.000]$} & {$[0.000]$} \\
5 & $0.0762^{* * *}$ & $0.1148^{* * *}$ & $0.1072^{* * *}$ & $0.0923^{* * *}$ & $0.0756^{* * *}$ \\
& {$[0.000]$} & {$[0.000]$} & {$[0.000]$} & {$[0.000]$} & {$[0.000]$} \\
6 & $0.0785^{* * *}$ & $0.1213^{* * *}$ & $0.1139^{* * *}$ & $0.0986^{* * *}$ & $0.0795^{* * *}$ \\
& {$[0.000]$} & {$[0.000]$} & {$[0.000]$} & {$[0.000]$} & {$[0.000]$} \\
\hline
\end{tabular}

Notes: The entries are the BDS test statistics and p-values are within brackets. The parameter $m$ is the embedding dimension. *** Indicates rejection of unit root at the $1 \%$ level of significance

\section{RESULTS FROM LINEAR MODEL}

We developed a linear regression model in which the stock returns of each ASEAN-5 country are regressed on decomposed oil price shocks series based on (4). The results are presented in Table 4 . With no regime switching effects, the calculated coefficients from the linear regression model are treated as baseline results to capture the influence of oil shocks on stock returns. We observe that supply shock has mixed impact on ASEAN-5 stock returns. The estimated coefficient of supply shock variable is negative and statistically significant for the Philippines and Thailand (oil importers), positively significant for Indonesia (oil exporter), but statistically insignificant for Malaysia and
Singapore. For demand shock, the impacts are positively significant for all stock returns. In contrast, the coefficients of risk shocks are negative and statistically significant for all ASEAN-5, indicating that the risk component of oil shock balances the influence of demand shocks on stock return. Although most of the slope coefficients are statistically significant, the explanatory power of (4) still appear to be weak with $\mathrm{R}$-squared values varying from as low as $0.1 \%$ for Malaysia to the highest of $4 \%$ for Singapore. Low R-squared statistics denotes model specification bias. It implies the presence of an asymmetric link between oil price shocks and stock returns that cannot be detected when estimating a linear regression model.

TABLE 4. Linear model regression

\begin{tabular}{lcccccc}
\hline \multicolumn{1}{c}{ Country } & Intercept & $S$ & $D$ & $V$ & $\mathrm{R}^{2}$ & LL \\
\hline Malaysia & $0.0150^{* * *}$ & 0.0002 & $0.0024^{* *}$ & $-0.0004^{* *}$ & 0.001399 & -14307.1 \\
& $(0.0011)$ & $(0.0005)$ & $(0.0011)$ & $(0.0002)$ & & \\
Indonesia & 0.0024 & $0.0778^{* * *}$ & $0.3328^{* * *}$ & $-0.0252^{* *}$ & 0.005679 & -24067.1 \\
& $(0.0631)$ & $(0.0293)$ & $(0.0604)$ & $(0.0099)$ & & \\
Philippines & 0.0277 & $-0.0221^{* *}$ & $0.1199 * * *$ & $-0.0067 * *$ & 0.00636 & -15533.1 \\
& $(0.0198)$ & $(0.0092)$ & $(0.0191)$ & $(0.0031)$ & & \\
Singapore & 0.0065 & -0.0159 & $0.3144 * * *$ & $-0.0340^{* * *}$ & 0.03987 & -15842.6 \\
& & & & & \\
& $(0.0222)$ & $(0.0106)$ & $(0.0212)$ & $(0.0035)$ & & \\
Thailand & $0.0549 * *$ & $-0.0389 * * *$ & $0.3605 * * *$ & $-0.0344 * * *$ & 0.03936 & -17260.9 \\
& $(0.0247)$ & $(0.0114)$ & $(0.0237)$ & $(0.0039)$ & & \\
\hline
\end{tabular}

Notes: Standard deviation are shown parenthesis. Regression estimates are derived from model Equation 4. $S$ denotes supply shocks, $D$ denotes demand shocks, $V$ denotes risk shocks, LL denotes maximized log likelihood.

**, *** Denotes statistical significance at the $5 \%$ and $1 \%$ levels 


\section{RESULTS FROM SWITCHING REGRESSION}

In an effort to capture the nonlinear influence of oil shocks on stock returns, Table 5 presents the outcomes from the two-state Markov regime-switching time-series model for five ASEAN countries. Switching regression coefficients are reported on Panel 1, while Panel 2 reports the transitional probabilities. We define regime 1 as the high volatility state, and regime 2 as the low volatility state. The magnitude of volatility is determined by the overall size of standard deviation (sigma) of each regime. The regime with the higher (lower) coefficients' standard deviations is the high (low) volatility regime. From Panel 1 , each coefficient's standard deviation in regime 1 is about 3 to 6 times larger than the coefficients' standard deviations in regime 2. For example, for Malaysia, the standard deviations for supply shocks, demand shocks and risk shocks in regime 1 are 0.0306, 0.0701 and 0.0120, respectively; while those of regime 2 are $0.0062,0.0114$ and 0.0018 , respectively.

For demand shocks and risk shocks, we found no significant regime effects on stock returns for all countries. This is because the coefficients' signs remain the same across regimes. Although there is no significant regime effect, for regime 1, the explanatory influences of demand shocks and risk shocks are consistently higher than regime 2. Regarding demand shock, the impact on stock return is positive for both regimes, regardless of the nature of oil-dependence of the country (with one exception for the Philippines). Results for oil demand shocks are consistent with the United States' stock market published in the study by Ready (2018). One possible justification is that positive oil demand shocks reflect increased world economic growth. This is perceived as positive signs for equity markets; hence attracting funds to risky shares as the appetite for risk increases globally. Unsurprisingly, we found that the biggest impact of oil demand shocks occurred in Indonesia with an estimated coefficient of 0.6445 , one of the leading oil producers in ASEAN. The positive effect on stock returns from oil demand shocks is also consistent with the findings from structural VAR model of Kilian (2009) on different countries and time periods (Basher et al. 2018, 2012; Wang et al. 2013; Zhu et al. 2017).

As expected, there is a negative exposure to risk shocks on all stock markets, which is indicated by significant negative risk shocks coefficients. The negative effect of risk shocks reflects the adverse impact of risks aversion or uncertainty in the stock market, in line with evidence from Banerjee et al. (2007) and Zhu (2013). Historically, the oil market has endured major transformations that influence the association between oil prices and systemic equity risk factors. This relationship deepened during the pre and post GFC as investors sought to sell their assets to meet declining equity market margin requirements. Thus, when oil market faces heighten uncertainty, as shown by the prolonged drop in crude oil price (e.g. June 2014-present day in Figure 1), it adversely affects both oil-importing and oil-exporting countries' stock-market returns, which is consistent with the arguments of Ramos and Veiga (2013). The significant negative effect of risk shock may also be due to high dependency of Asian stock market on crude oil price changes regardless of the level of stock returns (Ding et al. 2016). The elasticity between oil shocks and stock prices is higher during high volatility period than low volatility period, which is similar to an observation documented by Reboredo (2008). This is evident by the size of risk shock coefficients in regime 1 compared to that of regime 2 . This further justifies the nonlinearity relationship between energy-related stock returns and oil shocks among the five ASEAN countries.

In the case of supply shocks, findings show that oil supply shocks do not impact stock returns significantly for Malaysia and Singapore. For Indonesia (oil exporter), supply shocks have a significant positive effect only in high volatility state, but it is insignificant in low volatility state. However, in the case of Thailand (oil importer), the effects of supply shocks are negative and significant in regime 1 but are not significant in regime 2 . Similar finding is found in the Philippines (oil importer), despite the supply shock coefficient for the Philippines is weak significant in regime 1. Overall, the effects of supply shocks on equity returns are limited, concurring the findings of Basher et al. (2018) and Zhu et al. (2017). For oil exporting country like Indonesia, the response of energy-related stock prices to supply shocks can be explained by the differences in the elasticity of oil demand in the short-run and long-run. According to Hamilton (2009), although the demand for crude oil is highly inelastic in the short-run, its elasticity in the long-run is greater. Therefore, a positive supply shock that causes a decrease in oil price may not necessarily increase oil demand in the short run, whereby causing profits to drop and stock prices to decline. However, a persistent decrease in oil price over a longer period may induce oil importing countries to consume more oil, which in turn raises the profits and stock prices of oil exporting country. The opposite argument is true in the case of oil importing countries like Thailand and Singapore. A sustained positive oil shock will negatively affect firms' profits and lower stock returns in the long term.

In panel 2, we report the smooth transition probabilities for the five ASEAN countries. The elements of the transition probability matrices $\mathrm{P} 11$ and $\mathrm{P} 22$ show the approximate probability of staying in State (Regime) 1 and State (Regime) 2 in the current period, respectively. 
Overall, the ASEAN countries, excluding Indonesia record strong persistent regime as the probabilities of P11 and P22 are high, exceeding $80 \%$. For example, the results for Thailand indicate that is a $95 \%$ probability of staying in high volatility regime, and a $90 \%$ probability of staying in low volatility regime. Stated differently, once in regime 1 (or 2), the process is likely to remain. This shows that only an extraordinary circumstance can switch the series between a high volatility and a low volatility. As for Indonesia, the switching pattern is less persistent in Regime 1 . With probability of 0.46 , the processes switch from state 1 to state 2 in the next period. However, once the process is in Regime 2, it has an $81 \%$ probability of staying. Generally, the estimated transition probabilities show that all regimes are temporary because all the transition probabilities are less than one. Figure 4 plots the smooth probabilities of the high volatility states conditioned on historical and contemporary sample information.

Finally, we examined the R-squared of MRS and compared them with that from the linear regression in Table 4. As we compare between the two regressions, in most cases, it is evident that the R-squared from MRS is constantly higher than the R-squared in linear model. For example, referring to Malaysia, Indonesia and the Philippines, R-squared values in the linear model (Table 4) are $0.0014,0.0056$ and 0.006 , respectively, whereas for regime 1, the values are 0.0177, 0.0109, and 0.0137, respectively; in which they are 116, 92 and $115 \%$ higher, accordingly. For Singapore and Thailand, the low volatility (regime 2) R-squared is $47 \%$, and is $82 \%$ more than the R-squared obtained from the linear regression.

Overall, such findings have two consequences. First, different values of $\mathrm{R}$-squared between regimes indicate the presence of asymmetric relationship between the estimated variables that the linear model cannot capture. Second, in comparison with the linear model, higher MRS' R squared shows the superiority of the regime switching regression has over the linear model. Thus, implying that the use of MRS regression to address the nonlinear association between oil price shocks and stock returns is appropriate.

TABLE 5. Markov Regime Switching Regression

\begin{tabular}{|c|c|c|c|c|c|c|c|}
\hline \multicolumn{8}{|c|}{ Panel A: estimated coefficients } \\
\hline Country & State & Intercept & $S$ & $D$ & V & $\mathrm{R}^{2}$ & LL \\
\hline \multirow[t]{4}{*}{ Malaysia } & $\mathrm{S} 1$ & 0.0288 & -0.0457 & $0.1735^{*}$ & $-0.0464 * * *$ & 0.0177 & -12223 \\
\hline & & $(0.0946)$ & $(0.0306)$ & $(0.0701)$ & $(0.012)$ & & \\
\hline & S2 & 0.0153 & -0.01 & $0.0801 * * *$ & $-0.0107 * * *$ & 0.0173 & \\
\hline & & $(0.0116)$ & $(0.0062)$ & $(0.0114)$ & $(0.0018)$ & & \\
\hline \multirow[t]{4}{*}{ Indonesia } & S1 & 0.0942 & $0.2572 * * *$ & $0.6445 * * *$ & $-0.0637^{*}$ & 0.0109 & -18254 \\
\hline & & $(0.1733)$ & $(0.0948)$ & $(0.1743)$ & $(0.0339)$ & & \\
\hline & S2 & $-0.0314 * *$ & -0.0021 & $0.1201 * * *$ & $-0.0073 * * *$ & 0.0183 & \\
\hline & & $(0.0143)$ & $(0.0068)$ & $(0.0162)$ & $(0.0023)$ & & \\
\hline \multirow[t]{4}{*}{ Philippines } & S1 & $0.1637 * * *$ & $-0.0444 *$ & $0.2615 * * *$ & -0.0094 & 0.0137 & -12895 \\
\hline & & $(0.056)$ & $(0.023)$ & $(0.0475)$ & $(0.008)$ & & \\
\hline & S2 & $-0.0421 * * *$ & -0.0055 & 0.0071 & $-0.0036^{* *}$ & 0.0016 & \\
\hline & & $(0.01)$ & $(0.0051)$ & $(0.0101)$ & $(0.0017)$ & & \\
\hline \multirow[t]{4}{*}{ Singapore } & S1 & $0.1628 * *$ & -0.0391 & $0.4088^{* * *}$ & $-0.0498 * * *$ & 0.0426 & -13696 \\
\hline & & $(0.0792)$ & $(0.0303)$ & $(0.0562)$ & $(0.0108)$ & & \\
\hline & S2 & $-0.0468 * * *$ & 0.0031 & $0.2114 * * *$ & $-0.0235^{* * *}$ & 0.0587 & \\
\hline & & 0.0134 & 0.0082 & 0.0167 & 0.0024 & & \\
\hline \multirow[t]{4}{*}{ Thailand } & S1 & $0.126^{*}$ & $-0.0766 * * *$ & $0.3817 * * *$ & $-0.053 * * *$ & 0.0350 & -15872 \\
\hline & & $(0.0715)$ & $(0.0254)$ & $(0.0564)$ & $(0.0106)$ & & \\
\hline & S2 & $0.0241 * *$ & -0.0012 & $0.3277 * * *$ & $-0.0236 * * *$ & 0.0717 & \\
\hline & & $(0.0095)$ & $(0.0261)$ & $(0.021)$ & $(0.0028)$ & & \\
\hline
\end{tabular}




\begin{tabular}{lccccc}
\hline \multicolumn{1}{c}{ Country } & P11 & P12 & P21 & P22 & AIC \\
\hline Malaysia & 0.9549 & 0.0450 & 0.1941 & 0.8058 & 24462 \\
Indonesia & 0.5435 & 0.4564 & 0.1873 & 0.8126 & 36524 \\
Philippines & 0.8243 & 0.1756 & 0.0917 & 0.9082 & 25806 \\
Singapore & 0.9402 & 0.0597 & 0.1648 & 0.8351 & 27409 \\
Thailand & 0.9547 & 0.0452 & 0.0960 & 0.9039 & 31761 \\
\hline
\end{tabular}

Notes: Standard deviation are shown parenthesis. Regression estimates are derived from model Equation 5. $S$ denotes supply shocks, $D$ denotes demand shocks, $V$ denotes risk shocks, LL denotes maximized log likelihood.

$*, * *, * *$ Denotes statistical significance at the $10 \%, 5 \%$ and $1 \%$ levels

Conclusion

Malaysia

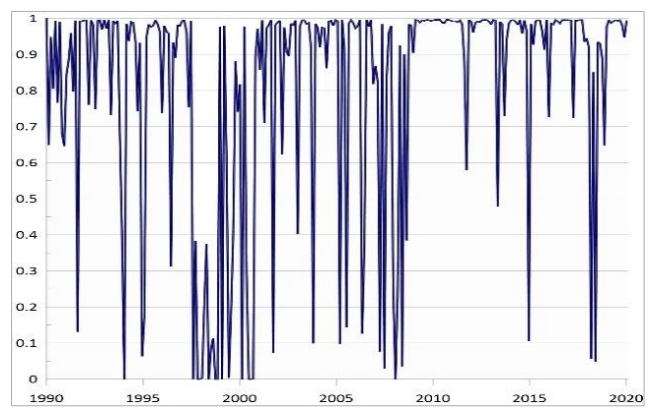

Philippines

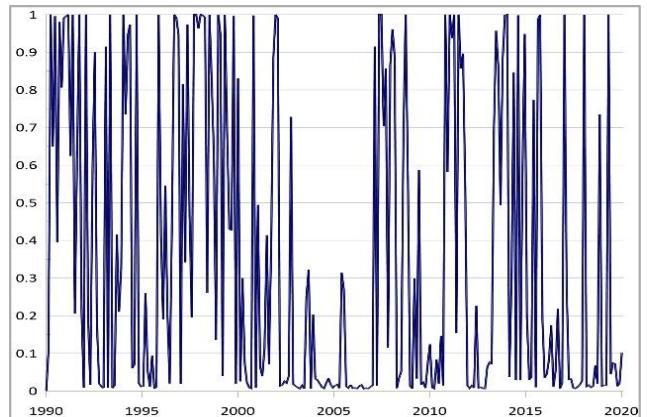

Indonesia

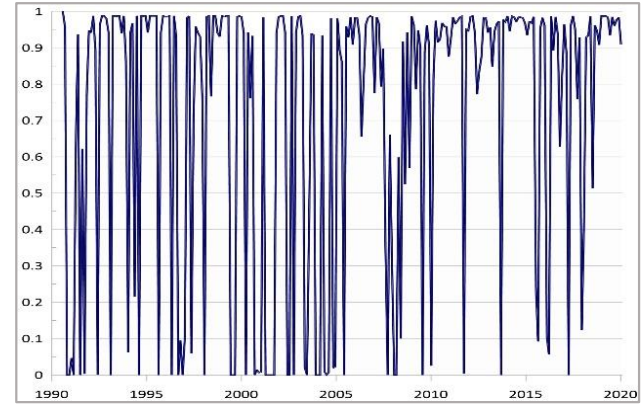

Singapore

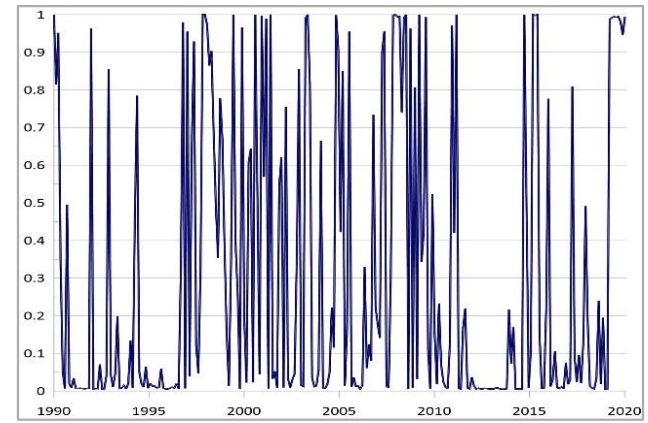

Thailand

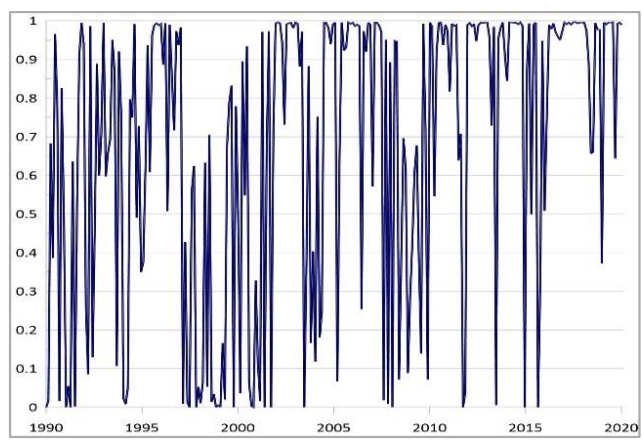

FIGURE 4. Smoothed probability for regime 1 
This paper sets out to examine the effects of disentangled oil price shocks on daily stock returns for the selected five ASEAN countries. Unlike most studies that focus only on developed countries and emerging economic blocs, such as BRICS, our attention is devoted to ASEAN economies. Furthermore, while a bulk of studies have assessed broad market indices, few studies have thus far tested the oil price-stock return nexus at sectoral level, namely energy related sector. Our study focuses on energy-related stock market with respect to oil price shocks and provides new evidence on asymmetries in the relationship by using daily data from January 1990 to January 2020. The estimation procedure involves two steps. First, the oil price shocks are decomposed into supply, demand and risk components based on the identification approach developed by Ready (2018). Next, we estimate the asymmetric impacts of oil price shocks on stock returns by utilising a two-regime Markov regime-switching method. This method enables the coefficient of regression and the variance to be different across states.

Our empirical results demonstrate that the tworegime Markov regime-switching model performs better than the baseline linear regression model. Specifically, the R-squared from MRS is constantly higher than the $\mathrm{R}$-squared of linear model for all the five ASEAN countries. The MRS regression provides a confirmation of strong nonlinear responses of stock returns to risk shocks and demand shocks, albeit the absence of strong regime effect between the high volatility and low volatility. On the contrary, the impact of supply shocks on stock returns is found to be dependent on regimes. This is as demonstrated by differing signs and size of coefficients for the case of Indonesia, the Philippines and Singapore. We illustrate that positive demand shocks are positively correlated with stock returns, whereas positive risk shocks significantly reduce stock returns (with one exception). Furthermore, we show that effects of supply shocks on stock returns are statistically insignificant in a low-volatility regime, and minimal impact in high-volatility regime for several countries. In general, stock returns are influenced more by demand-driven shocks than supply and risk shocks. This is as evident by the magnitude and statistical significance of the coefficients. This result illustrates the greater economic impact of demand shock has on an economy when compared to supply and risk shocks.

Our findings should be of interest to market participants and regulators. First, risk mitigating strategy, such as hedging in future prices of crude oil and having safety net in cash balances and oil reserves and oil reserves in a tumultuous period would cushion market crashes for these energy-related firms. This is critical especially for oil-dependent industries to protect themselves against risks due to oil price fluctuations during bearish or bullish markets. The recent event of Covid-19 pandemic coupled with oil price war between Saudi and Russia had spiraled the oil price to USD13 briefly in late April 2020. The outlook is worrying especially for oil exporting countries and could deepen the recession in post-pandemic period.

Second, policy makers should pursue effective policies to reduce the systemic risk of oil stocks under adverse conditions. The disruptive shocks such as pandemic, geopolitical war and natural disaster require flexibility and concerted efforts on long term initiatives such as reducing oil price trade war, as well as improving supply chain and logistic. Carbon footprint reduction and production control must be part of regional governmental policy to reduce oil glut. This is because economic growth in the region relies heavily on the cooperation between the oil exporting countries and the oil importing countries.

\section{REFERENCES}

Adaramola, A.A. 2012. Oil price shocks and stock market behaviour: The Nigerian experience. Journal of Economics 3(1): 19-24.

Aloui, C., Nguyen, D.K. \& Njeh, H. 2012. Assessing the impacts of oil price fluctuations on stock returns in emerging markets. Economic Modelling 29(6): 2686-2695.

Arouri, M.E.H., Lahiani, A. \& Nguyen, D.K. 2011. Return and volatility transmission between world oil prices and stock markets of the GCC countries. Economic Modelling 28(4): 1815-1825.

Awartani, B. \& Maghyereh, A.I. 2013. Dynamic spillovers between oil and stock markets in the Gulf Cooperation Council countries. Energy Economics 36: 28-42.

Badeeb, R.A. \& Hooi, H.L. 2018. Asymmetric impact of oil price on Islamic sectoral stocks. Energy Economics 71: 128-139.

Bakri, A. \& Abdul-Rahman, A. 2020. Market integration in Asean-5: Evidence of Islamic and conventional stock markets. Polish Journal of Management Studies 21(1): 186-198.

Banerjee, P.S., Doran, J.S. \& Peterson, D. 2007. Implied volatility and future portfolio returns. Journal of Banking \& Finance 31(10): 3183-3199.

Basher, S.A., Haug, A.A. \& Sadorsky, P. 2012. Oil prices, exchange rates and emerging stock markets. Energy Economics 34(1): 227-240.

Basher, S.A., Haug, A.A. \& Sadorsky, P. 2018. The impact of oil-market shocks on stock returns in major oil-exporting countries. Journal of International Money and Finance 86: 264-280.

Basnet, H.C. \& Upadhyaya, K. 2015. Impact of oil price shocks on output, inflation and the real exchange rate: Evidence from selected ASEAN countries. Applied Economics 47(29): 3078-3091.

Bollerslev, T., Tauchen, G. \& Zhou, H. 2009. Expected stock returns and variance risk premia. Review of Financial Studies 
22: 4463-4492.

Bouri, E. 2015. Return and volatility linkages between oil prices and the Lebanese stock market in crisis periods. Energy 89: 365-371.

Bouri, E., Awartani, B. \& Maghyereh, A. 2016. Crude oil prices and sectoral stock returns in Jordan around the Arab uprisings of 2010. Energy Economics 56: 205-214.

Broadstock, D.C., Cao, H. \& Zhang, D. 2012. Oil shocks and their impact on energy related stocks in China. Energy Economics 34(6): 1888-1895.

Broadstock, D.C., Wang, R. \& Zhang, D. 2014. Direct and indirect oil shocks and their impacts upon energy related stocks. Economic Systems 38(3): 451-467.

Brock, W.A., Dechert, W.D., Scheinkman, J.A. \& LeBaron, B. 1996. A test for independence based on the correlation dimension. Econometric Reviews 15: 197-235.

Cunado, J. \& Gracia, F. 2014. Oil price shocks and stock market returns: Evidence for some European countries. Energy Economics 42: 365-377.

Darinda, D. \& Permana, F. 2019. Volatility spillover effects in Asean-5 stock market: Does the different oil price era change the pattern? Kajian Ekonomi dan Keuangan 3(2): 116-134.

Demirer, F., Roman, F. \& Shahzad, S.J.H. 2019. Oil price shocks and financial markets: A comparative analysis of stock and sovereign bond markets (Unpublished).

Ding, H., Hyung, K. \& Sung, P. 2016. Crude oil and stock markets: Causal relationships in tails? Energy Economics 59: 58-69.

Elliott, G., Rothenberg, T. \& Stock, J. 1996. Efficient tests for an autoregressive unit root. Econometrica 64(4): 813-836.

Elyasiani, E., Mansur, I. \& Odusami, B. 2011. Oil price shocks and industry stock returns. Energy Economics 33(5): 966974.

Granger, C.W. 1996. Can we improve the perceived quality of economic forecasts? Journal of Applied Econometrics 11(5): 455-473.

Ghosh, S. \& Kanjilal, K. 2016. Co-movement of international crude oil price and Indian stock market: Evidences from nonlinear cointegration tests. Energy Economics 53: 111-117.

Gupta, K. 2016. Oil price shocks, competition, and oil \& gas stock returns - global evidence. Energy Economics 57: 140-153.

Hamilton, J.D. 2009. Understanding crude oil prices. The Energy Journal 30(2): 179-206

Hamilton, J.D. 1989. A new approach to the economic analysis of nonstationary time series and the business cycle. Econometrica 57: 357-384. http://dx.doi.org/10.2307/1912559.

Hamidreza, M. \& Maryam, S. 2012. Point forecast Markov switching model for U.S. Dollar/ Euro exchange rate. Sains Malaysiana 41(4): 481-488.

Hansen, B.E. 2001. The new econometrics of structural change: Dating breaks in US labour productivity. Journal of Economic Perspectives 15(4): 117-128.

Hersugondo, S.E., Robiyanto, R., Wahyudi, S. \& Muharam, H. 2015. The world oil price movements and stock returns in several Southeast Asia's capital markets. IJABER 13(2): $527-534$
Hossenidoust, E., Janor, H., Yusefi, M., Majid, H.A. \& Ja'afar, R. 2013. Volatility spillovers across commodity and stock markets among ASEAN countries. In Persidangan Kebangsaan Ekonomi Malaysia VIII (PERKEM VIII). Johor Bahru. pp. 1401-1412.

Hoque, M.E., Wah, L.S. \& Shah Zaidi, M.A. 2019. Oil price shocks, global economic policy uncertainty, geopolitical risk, and stock price in Malaysia: Factor augmented VAR approach. Economic Research-Ekonomska Istraživanja 32(1): 3700-3732.

Hoque, M.E. \& Shah Zaidi, M.A. 2019. The impacts of global economic policy uncertainty on stock market returns in regime switching environment: Evidence from sectoral perspectives. International Journal of Finance and Economics 24(2): 991-1016.

Ismail, M.T. \& Isa, Z. 2006. Modelling exchange rate using regime switching models. Sains Malaysiana 35(2): 55-62.

Kang, W., de Gracia, F. \& Ratti, R. 2017. Oil price shocks, policy uncertainty, and stock returns of oil and gas corporations. Journal of International Money and Finance 70(C): 344-359.

Kilian, L. 2009. Not all oil price shocks are alike: Disentangling demand and supply shocks in the crude oil market. American Economic Review 99(3): 1053-1069.

Kilian, L. \& Park, C. 2009. The impact of oil price shocks on the U.S. Stock Market. International Economic Review 50(4): 1267-1287.

Kisswani, K. 2016. Does oil price variability affect ASEAN exchange rates? Evidence from panel cointegration test. Applied Economics 48(20): 1831-1839.

Kobayashi, K., Rashid, K.A., Furuichi, M. \& Anderson, W.P. 2018. Economic Integration and Regional Development: The ASEAN Economic Community. New York: Routledge.

Kwiatkowski, D., Phillips, P.C.B., Schmidt, P. \& Shin, Y. 1992. Testing the null hypothesis of stationarity against the alternative of a unit root: How sure are we that economic time series have a unit root? Journal of Econometrics 54(1-3): 159-178.

Lee, B., Yang, C.W. \& Huang, B. 2012. Oil price movements and stock markets revisited: A case of sector stock price indexes in the G-7 countries. Energy Economics 34(5): $1284-1300$.

Manal, A. \& Tamat, S. 2020. The inter-relationship between commodity energy prices and stock market volatility in Saudi-Arabia. Journal of Nusantara Studies 5(1): 270-293.

Maneeju, P., Yamaka, W. \& Sriboonchitta, S. 2018. MixedCopulas approach in examining the relationship between oil prices and ASEAN's stock markets. In Econometrics for Financial Applications. Germany: Springer. pp. 531-541.

Pan, M. \& Nguyen, H. 2018. Export and growth in ASEAN: Does export destination matter? Journal of Chinese Economic and Foreign Trade Studies 11(2): 122-131.

Ramos, S.B. \& Veiga, H. 2013. Oil price asymmetric effects: Answering the puzzle in international stock markets. Energy Economics 38: 136-145.

Ready, R.C. 2018. Oil consumption, economic growth, and oil futures: The impact of long-run oil supply uncertainty on asset 
prices. Journal of Monetary Economics 94: 1-26.

Reboredo, J. 2008. Nonlinear effects of oil shocks on stock returns: A Markov-switching approach. Applied Economics 42(29): 3735-3744

Sakane, K. 2018. ASEAN Integration: Opportunities and Challenges. In Economic Integration and Regional Development. New York: Routledge. pp. 11-33.

Sadorsky, P. 1999. Oil price shocks and stock market activity. Energy Economics 21: 449-469.

Samsuddin, S. \& Ismail, N. 2019. Markov chain model and stationary test: A case study on Malaysia Social Security (SOCSO). Sains Malaysiana 48(3): 697-701.

Uddin, G.S., Rahman, M.L., Shahzad, S.J.H. \& Rehman, M.U. 2018. Supply and demand driven oil price changes and their non-linear impact on precious metal returns: A Markov regime switching approach. Energy Economics 73: 108-121.

$\mathrm{Vu}$, T.K. \& Nakata, H. 2018. Oil price fluctuations and the small open economies of Southeast Asia: An analysis using vector auto-regression with block exogeneity. Journal of Asian Economics 54: 1-21.

Wang, Y., Wu, C. \& Yang, L. 2013. Oil price shocks and stock market activities: Evidence from oil-importing and oilexporting countries. Journal of Comparative Economics 41: 1220-1239.

Zhu, H., Su, X., You, W. \& Ren, Y. 2017. Asymmetric effects of oil price shocks on stock returns: Evidence from a two-stage
Markov regime-switching approach. Applied Economics 49: 2491-2507.

Zhu, M. 2013. Return distribution predictability and its implications for portfolio selection. International Review of Economics \& Finance 27: 209-223.

Adilah Azhari, Mukhriz Izraf Azman Aziz \& Yong Kang Cheah

Department of Economics and Agribusiness

School of Economics, Finance and Banking

Universiti Utara Malaysia

06010 Sintok, Kedah Darul Aman

Malaysia

Hazrul Shahiri*

Centre of Inclusive and Sustainable Development

Faculty of Economics and Management

Universiti Kebangsaan Malaysia

43600 UKM Bangi, Selangor Darul Ehsan

Malaysia

*Corresponding author; email: hizuan@ukm.edu.my

Received: 21 May 2020

Accepted: 8 September 2020 